\title{
ISLAMIC SOCIAL REPORTING: THE DIFFERENCE OF PERCEPTION BETWEEN USER AND PREPARER OF ISLAMIC BANKING IN INDONESIA
}

\author{
Dhiona Ayu Nani \\ Accounting, Universitas Teknokrat Indonesia, Lampung \\ e-mail: dhiona.a@teknokrat.ac.id
}

\begin{abstract}
Islamic banking has functions that are not merely oriented towards gaining profit but also related to social roles in society. Muhammad (2010) explains that financial report makers as part of companies tend to minimize reporting costs to ensure cost efficiency because their main goal is economic performance. On the other hand, users who represent the community expect Islamic banking to have social accountability because the existence of these companies is within the community. Therefore, the discussion about accountability of Islamic banking in the social field becomes interesting to be studied. This study aims to determine the perceptions of users and preparers of financial statements on the main objectives of Islamic banking social report, the motivation of Islamic banking to present social report, the potential groups of social report users and the information that must be disclosed on a social report. This study uses two types of respondents, namely the users represented by lecturers and students and the preparers represented by Islamic Bank employees in one of the big cities in Indonesia. The analytical method used is t-test and Multiple Response Analysis.The results of the study show that there are no differences in perceptions between the users and preparers of financial statements towards the main objectives of Islamic banking social report, the motivation of Islamic banking to present social report and potential users of Islamic banking social report.Meanwhile, there is the difference in perceptions between users and preparers of financial statements of information that must be disclosed in the Islamic banking social report.
\end{abstract}

Keywords: Islamic Banking, SocialReporting in Islamic Perspective, Accountability.

\section{Introduction}

In the past ten years, the development of Islamic Banks has progressed rapidly. In addition to Sharia Banks, non-Bank Islamic financial institutions also experience the same thing. It shows that the Islamic economic system can be well received by the Indonesian people who are predominantly Muslim. Sharia Banking Regulation No. 21 of 2008 states that sharia banking is everything that concerns Sharia Banks and Sharia Business Units, including institutions, business activities, and ways and processes in carrying out their business activities. Sharia Banks are Banks that carry out their business activities based on Sharia principles and according to their types consist of Sharia Commercial Banks (BUS), Sharia Business Units (UUS), and Sharia Rural Financing Banks (BPRS). The existence of Islamic Banking is closely related to social responsibility.Fitria and Hartanti (2010) stated that related to the need for disclosure of social responsibility in sharia banking, it is currently discussed about the Islamic Social Reporting (ISR).ISR is a standard item of Corporate Social Responsibility (CSR) established 
by the Accounting and Auditing Organization for Islamic Financial Institutions (AAOIFI) which should be disclosed by an Islamic entityThe ISR index is believed to be a starting point in terms of CSR disclosure standards that are in line with the Islamic perspective. The aim is to establish CSR standards in Islamic financial institutions, both obligations and standards suggested to implement CSR in all aspects of the activities of Islamic financial institutions and provide guidance on disclosure of CSR information to stakeholders from Islamic financial institutions. Islamic banking is based on the principles of transparency. Transparency is an important element of the accountability function for Islamic financial institutions to those interested in the company, because this allows them to evaluate and measure the level of social responsibility. The principle of transparency makes Islamic Banking disclose company information to users of information in the form of financial statements.

Financial statements are a source of financial information that is very useful for all parties interested in the continuity of the company. Every company is obliged to present financial information to inform all interested parties of financial statements for the company's economic decision making (Haryono, 2009: 24). In addition, financial statements also provide information about management accountability for the trust given by users of financial statements. The company must present financial statements in accordance with the actual conditions of the company. Haryono (2009: 24) also explained that the presentation of financial statements honestly would increase the reliability and accuracy of the information presented.But there are not a few cases of fraud in the preparation of financial statements. Muhammad (2010) explains that financial report makers as part of companies tend to minimize reporting costs to ensure cost efficiency because their main goal is economic performance. On the other hand, users who represent the community expect Islamic banking to have social accountability because the existence of these companies is within the community.The difference in views and thoughts is known as perception. Differences in perception in Islamic banking can occur between users and preparers of financial statements. This study aims to investigate differences in perceptions between users and preparers of financial reports in Islamic banking social reporting in Indonesia. This research is an extension of Muhammad (2010) that examine the needs of Islamic banking social reporting from the perspective of certain stakeholders in Malaysia.

\section{Literature Review}

\subsection{Stakeholder Theory}

The company is influenced by internal and external factors that can be referred to as stakeholders. Stakeholders are people or groups of people who can influence or be influenced by various decisions, policies, and operations of the company.Gray, Kouhy and Adams (1994) state that the survival of a company depends on the support of stakeholders and that support must be sought so that the company's activities are to seek that support.The stakeholders are divided into two, namely internal parties and external parties. Internal parties themselves are shareholders, management, employees. While from external parties are investors, creditors, consumers, suppliers, communities, the government. Ghozali and Chariri (2007) state that companies are not entities that only operate for their own interests but must provide benefits to their stakeholders. One of the benefits that the company can provide to its stakeholders 
is by disclosing the company's social information. Disclosure of corporate social information is considered as part of the dialogue between the company and its stakeholders. This information is a form of corporate responsibility towards stakeholders.

\subsection{User and Preparer Perception}

Perception is one of the important psychological aspects for humans in responding to the presence of various aspects and symptoms around it. Every individual's perception can be different. These differences can be influenced by many factors, including knowledge, experience and point of view. Differences in perception in Islamic banking can occur between users and preparers of financial statements. Users tend to want the attitude of transparency from the preparer in the form of social responsibility to the company's stakeholders, but not a few of the preparers who only prioritize company profits without thinking of good relations with the company's stakeholders. Anto (2008) states that in reality there are still many Sharia Banks which prioritize the attainment of maximum profits, like Conventional Banks so far, whereas they should include a component of social responsibility in their operational activities as the ultimate goal in serving the community as a whole.

\subsection{Islamic Banking in Indonesia}

Sharia Bank is a financial institution engaged in the business of providing credit and other services in the payment and circulation of money whose operations are adjusted to Islamic principles. At the time of the Prophet Muhammad the practice of usury was already there. He forbids usury because it is difficult for human life. After the leadership was replaced by his pal, a bank was established with the aim of helping the economy of the people and regulating the economy of the country without taking interest from its customers because all operational costs were borne by the government which was taken from paying taxes for non-Muslims living there. Lately, usury has been discussed by the public because the current religious knowledge of the community is getting higher so that people start trying to avoid usury by using Islamic banks. As stated by Setiawan (2009) that the main reason for the existence of Islamic banking is the emergence of awareness of Muslim communities who want to carry out all their financial activities in accordance with religious guidelines. In Conventional Banking, the Board of Commissioners is known while Islamic Banking is known as the Sharia Supervisory Board (DPS) which is in charge of overseeing the operationalization of banks and products in accordance with sharia provisions.

\subsection{Social Reporting}

Social reporting or commonly known as CSR, is an action that reflects the company's responsibility towards corporate stakeholders such as consumers, shareholders and the environment. Zain (2014) argues that CSR is basically about an organization that stands alone and has responsibility for the surrounding environment in order to meet and satisfy the expectations of stakeholders. In Islamic organizations, CSR is commonly known as Islamic Social Reporting (ISR). ISR is reporting on the social performance of Islamic organizations. The aim of ISR is as a form of accountability to Allah SWT and society, and increasing transparency of business activities by presenting relevant information by paying attention to the spiritual needs of Muslim investors or sharia compliance in decision making (Haniffa, 2002).

\section{Hypothesis Development}


Financial report compilers are not only responsible to users of financial statements but also to Allah SWT. Financial report compilers must be trustworthy in conveying information. The aim in social reporting according to Haniffa (2002) is as accountability to Allah SWT and society, and increasing transparency of business activities by presenting relevant information by paying attention to the spiritual needs of Muslim investors or sharia compliance in decision making. But in practice, there have been various irregularities in Islamic banking activities, so this deviation certainly has an impact on the objective of social reporting. Muhammad (2010) explains that financial report makers as part of companies tend to minimize reporting costs to ensure cost efficiency because their main goal is economic performance, while users who represent the community expect Islamic Banking to have social accountability because the existence of the company is in the environment society. Different interests in social reporting can also be one of the factors that hinder the success of social reporting.

H1: There are differences in perceptions between users and preparers towards the main objectives in social reporting of Islamic banking.

$\mathrm{H} 2$ : There are differences in perceptions between the user and the preparer against the inhibiting factors in the social reporting of Islamic Banking.

Islamic banking as part of an Islamic organization, has a responsibility to provide social information to its stakeholders. This responsibility is a motivation for Islamic banks to implement banking practices in accordance with the rules and norms that have been regulated. In addition, the demands of the community towards companies to provide transparent information, organizations that have high accountability, and better corporate governance also increasingly force companies to provide information about their social activities (Marina, 2009). The community needs information about the extent to which the company has carried out its social activities so that community rights and employee welfare can be fulfilled. Motivation for preparers and users in disclosing social information should be the same, that is, they both want to uphold Islamic values. But in practice there is no assurance that the two parties have the same motivation.

H3: There are differences in perceptions between the user and the preparer for motivation that make it possible to disclose social reporting on Islamic Banking.

At present the desire to know the disclosure of corporate social reporting is getting higher. The company is expected not only to prioritize the interests of management and the company but also the interests of the community. The company has social responsibility towards parties outside the company who have an interest in the company. Putra (2012) explains that social responsibility reporting is aimed at users of financial statements and the annual reports of the company concerned and parties with an interest in the company, including shareholders, customers, suppliers, employees, and the public. For banking organizations, social reporting is also aimed at its customers. Banking customers, especially Islamic banking, have the right to know about social reporting

H4: There are differences in perceptions between users and preparers of the information users on social reporting of Islamic Banking. 
In line with the increasing implementation of CSR in the Islamic context, the desire to produce Islamic social reporting has also increased. There are two things that must be revealed by social reports in an Islamic perspective, namely: full disclosure and social accountability (Fitria and Hartanti, 2010). In addition, users also need to know information about company performance because this can be taken into consideration in decision making. Information about company performance in Islamic Banking includes information such as the responsibilities of the Sharia Supervisory Board (DPS), information on products and services, management of zakah, social activities, illegal transactions (haram), and corporate responsibility to employees and the public. Maali, Casson, and Napier (2006) describe several items that should be disclosed in Sharia Bank social reporting, namely (a) the submission of Sharia Supervisory Board Opinions, (b) submission of transactions that violate Sharia, (c) information on sources and distribution of zakah funds, ( d) information on the sources and distribution of QardhulHasan funds; (e) reporting on other social activities; (f) reporting of information on HR development, (g) disclosure of facts of treatment to customers who are late paying and / experiencing bankruptcy, (h) disclosure of information on environmental responsibility, and (i) aspects of Islamic banking involvement in community empowerment.

H5: There are differences in perceptions between users and preparers of information that must be disclosed in social reporting of Islamic Banking.

\section{Research Method}

The sample in this study was divided into two categories, namely the user and preparer of Islamic banking financial statements in one of the major cities in Indonesia. The user sample was represented by 48 students and 36 lecturers who had accounts in Islamic banks in the region. While for the preparer represented by 56 Islamic banking employees. The method used is a questionnaire survey adapted from several previous studies such as Maali, Casson, and Napier (2006) and Haniffa (2002). The data analysis using multiple response analysis and t-test. Validity and reliability are also used to test research instruments.

Table 1: Respon Rate

\begin{tabular}{llccc}
\hline \multicolumn{1}{c}{ Respondents } & $\begin{array}{c}\text { Distributed } \\
\text { questionnaires }\end{array}$ & $\begin{array}{c}\text { Questionnaire } \\
\text { that can be used }\end{array}$ & Respon Rate \\
\hline 1 & User: & 100 & 48 & $40 \%$ \\
& Students & 100 & 36 & $36 \%$ \\
& Lecturers & & & \\
Preparer: & 100 & 56 & $56 \%$ \\
& Sharia Bank employees & $\mathbf{3 0 0}$ & $\mathbf{1 4 0}$ & $\mathbf{4 6 . 6 \%}$ \\
\hline
\end{tabular}

\section{Result}

H1 results show a value of $0.401(>0.05)$ which means that there are no differences in perceptions between users and preparers of the main objectives of Islamic Banking social reporting, therefore $\mathrm{H1}$ is not supported. These results indicate that the user and preparer respondents have the same opinion that the main purpose of Islamic Banking social reporting is to show an attitude of accountability to God and society. For $\mathrm{H} 2$, the results show a value of 0.760 (> 0.05). this also shows that $\mathbf{H 2}$ is not 
supported. Both respondents argued that the possible factors that inhibit social reporting in Islamic Banking were the company's goals which emphasized economic performance rather than social performance.

For hypotheses 3 and 4, respondents are allowed to choose more than one answer. After being analyzed using multiple responses, a t-test is carried out.
Table 2: T-Test Hypothesis 1 \& 2

\begin{tabular}{lcc}
\hline & $\mathrm{N}$ & Mean \\
\hline Hypothesis 1 & & \\
User & 84 & 72.85 \\
Preparer & 56 & 66.98 \\
$\mathrm{t}$ & -0.839 & \\
Sig. (2-tailed) & 0.401 & \\
\hline Hypothesis 2 & & \\
User & 84 & 28.01 \\
Preparer & 56 & 28.28 \\
$\mathrm{t}$ & -0.306 & \\
Sig. (2-tailed) & 0.760 & \\
\hline
\end{tabular}

Table 3: Multiple Response for Hypothesis 3

\begin{tabular}{|c|c|c|c|c|c|c|c|}
\hline & \multirow{3}{*}{ Items } & \multicolumn{3}{|c|}{ User } & \multicolumn{3}{|c|}{ Preparer } \\
\hline & & \multicolumn{2}{|c|}{ Respondents } & \multirow{2}{*}{ Rank } & \multicolumn{2}{|c|}{ Respondents } & \multirow{2}{*}{ Rank } \\
\hline & & Total & $\%$ & & Total & $\%$ & \\
\hline 1 & $\begin{array}{l}\text { Sharia Banks must follow } \\
\text { sharia principles in their } \\
\text { operations }\end{array}$ & 82 & 24.1 & 1 & 51 & 23.7 & 1 \\
\hline 2 & $\begin{array}{l}\text { Social responsibility through } \\
\text { developing and empowering } \\
\text { the community is a form of } \\
\text { accountability to Allah SWT }\end{array}$ & 74 & 21.8 & 2 & 35 & 16.3 & 2 \\
\hline 3 & $\begin{array}{l}\text { Decision makers in Islamic } \\
\text { banks believe that disclosure } \\
\text { of social responsibility will } \\
\text { enhance their reputation in } \\
\text { society }\end{array}$ & 42 & 12.4 & 3 & 25 & 11.6 & 5 \\
\hline 4 & $\begin{array}{l}\text { Islamic banks must carry out } \\
\text { social responsibility } \\
\text { obligations to maintain their } \\
\text { existence in society }\end{array}$ & 42 & 12.1 & 4 & 30 & 14.0 & 4 \\
\hline 5 & $\begin{array}{l}\text { Sharia Banks must be seen } \\
\text { as social organizations and } \\
\text { their existence is justified as } \\
\text { long as they carry out } \\
\text { activities in accordance with } \\
\text { the objectives of the } \\
\text { community }\end{array}$ & 33 & 9.7 & 6 & 21 & 9.8 & 7 \\
\hline 6 & $\begin{array}{l}\text { Decision makers in Islamic } \\
\text { banks respect the concept of } \\
\text { social responsibility } \\
\text { disclosure }\end{array}$ & 42 & 12.4 & 5 & 31 & 14.4 & 3 \\
\hline 7 & $\begin{array}{l}\text { Decision makers in Islamic } \\
\text { banks understand how to } \\
\text { adopt methods of social } \\
\text { responsibility disclosure }\end{array}$ & 26 & 7.6 & 7 & 22 & 10.2 & 6 \\
\hline
\end{tabular}


Table 4: Multiple Response for Hypothesis 4

\begin{tabular}{|c|c|c|c|c|c|c|c|}
\hline & \multirow{3}{*}{ Items } & \multicolumn{3}{|c|}{ User } & \multicolumn{3}{|c|}{ Preparer } \\
\hline & & \multicolumn{2}{|c|}{ Respondents } & \multirow{2}{*}{ Rank } & \multicolumn{2}{|c|}{ Respondents } & \multirow{2}{*}{ Rank } \\
\hline & & Total & $\%$ & & Total & $\%$ & \\
\hline 1 & $\begin{array}{l}\text { Islamic Bank } \\
\text { Management }\end{array}$ & 75 & 11.0 & 1 & 45 & 12.7 & 1 \\
\hline 2 & $\begin{array}{l}\text { Mudharabah Savings / } \\
\text { Deposit Account Holders }\end{array}$ & 60 & 8.8 & 5 & 30 & 8.5 & 5 \\
\hline 3 & $\begin{array}{l}\text { Wadiah Savings Account } \\
\text { / Giro Account Holder }\end{array}$ & 54 & 7.9 & 9 & 28 & 7.9 & 8 \\
\hline 4 & Islamic Bank employees & 40 & 5.9 & 11 & 35 & 9.9 & 2 \\
\hline 5 & Sharia Bank Consumers & 56 & 8.2 & 7 & 34 & 9.6 & 3 \\
\hline 6 & $\begin{array}{l}\text { Amil Zakat (BAZNAS / } \\
\text { LAZ) }\end{array}$ & 55 & 8.1 & 8 & 29 & 8.2 & 7 \\
\hline 7 & $\begin{array}{l}\text { Investors / Shareholders } \\
\text { of Sharia Banks }\end{array}$ & 66 & 9.7 & 2 & 26 & 7.4 & 10 \\
\hline 8 & Potential Investors & 54 & 7.9 & 10 & 20 & 5.7 & 11 \\
\hline 9 & Government & 66 & 9.7 & 3 & 30 & 8.5 & 6 \\
\hline $\begin{array}{l}1 \\
0\end{array}$ & $\begin{array}{l}\text { Sharia Supervisory } \\
\text { Board (DPS) }\end{array}$ & 58 & 8.5 & 6 & 31 & 8.8 & 4 \\
\hline 1 & Islamic organizations & & & & & & \\
\hline 1 & $\begin{array}{l}\text { (NU, Muhammadiyah, } \\
\text { Persis, etc.) }\end{array}$ & 35 & 5.1 & 12 & 18 & 5.1 & 12 \\
\hline $\begin{array}{l}1 \\
2\end{array}$ & Muslims & 63 & 9.2 & 4 & 27 & 7.6 & 9 \\
\hline & Total & 682 & 100 & & 353 & 100 & \\
\hline
\end{tabular}

\begin{tabular}{lcc}
\hline & $\mathrm{N}$ & Mean \\
\hline Hypothesis 3 & & \\
User & 7 & 14.30 \\
Preparer & 7 & 14.285 \\
$\mathrm{t}$ & 0.005 & \\
Sig. (2-tailed) & 0.996 & \\
\hline Hypothesis 4 & & \\
User & 12 & 8.33 \\
Preparer & 12 & 8.32 \\
t & 0.011 & \\
Sig. (2-tailed) & 0.991 & \\
\hline
\end{tabular}

The table above shows the ranking of each statement chosen by the user and preparer respondents. The highest ranking of the hypothesis 3 statement, which is the motivation that allows for social reporting is the first item, namely a Sharia Bank must follow sharia principles in its operations. While the highest ranking of the hypothesis 4 statement is the potential user of the report is the first item, namely the management of Islamic

banks. After the items are ranked, then they are analyzed by t-test.

Table 5: T-Test Hypothesis 3 \& 4

Table 5 shows the value of 0.996 (>0.05) for hypothesis 3 , this means that there is no difference in perceptions between users and preparers of possible motivation in social reporting of Islamic Banking. Therefore Hypothesis 3 is not supported. This shows that the user and preparer groups have the same opinion that the possible motivation in social reporting Islamic Banking is to follow sharia principles in their operations and the concept of accountability to Allah SWT and society. Hypothesis 4 is also not supported, where the t-test shows a value of 0.991 (>0.05). This also means that the user and preparer groups have the same perception about the potential group of information users from Islamic Banking social reporting, namely the 
management of Islamic Banks, employees, consumers, shareholders and other parties who have interests in the company.

Testing hypothesis 5 also uses a t-test. The results show a significance value of $0.00(<0.05)$, therefore Hypothesis 5 is supported. This means that there are differences in perceptions between users and preparers of information that must be disclosed in the social reporting of Islamic Banking. Such information includes DPS responsibilities, product and service information, zakah management, illegitimate transactions and late payments by clients.

Table 6: T-Test for Hypothesis 5

\begin{tabular}{lcc}
\hline & $\mathrm{N}$ & Mean \\
\hline Hypothesis 5 & & \\
User & 7 & 14.30 \\
Preparer & 7 & 14.285 \\
$\mathrm{t}$ & 0.005 & \\
Sig. (2-tailed) & 0.996 & \\
\hline
\end{tabular}

\section{Conclusion}

Based on the results of hypothesis testing, it is known that only Hypothesis 5 is supported. The highest choice of respondents regarding information that must be disclosed in Islamic Banking social reporting is the Sharia Supervisory Board (DPS) report. The details of the information that received the highest choice from respondents were the responsibility of the Sharia Supervisory Board (DPS). In addition, the highest choice is also on information about products and services found in Islamic banks, illegal transactions, and responsibilities to employees and the public. Form of responsibility to employees, namely salary policies, training and equal opportunities among employees. Whereas for the community that is creating employment opportunities, support for organizations that provide benefits to the community and sponsor community activities. Meanwhile, the other four hypotheses cannot be supported by the educational background of the two groups of respondents who tend to be the same (bachelor and master) so that the respondents' point of view also tends to be the same. Finally this research can not be separated from limitations. The limitation lies in the response of preparer groups who cannot participate due to busy activities in the company's operations. For further research, it is expected to expand the research sample.

\section{References}

AAOIFI.(2001). Accounting and Auditing Standards for Islamic Financial Institutions.Manama: Accounting and Auditing Organization for Islamic Financial Institutions.

Anto, H., dan Astuti, D. R. (2008). Persepsi Stakeholder terhadap Pelaksanaan Corporate Social Responsibility: Kasus Pada Bank Syariah di DIY. SINERGI Kajian Bisnis dan Manajemen, 10(1), 19-30.

Fitria, S., dan Hartanti, D. (2010). Islam dan Tanggung Jawab Sosial: Studi Perbandingan Pengungkapan Berdasarkan Global Reporting Initiative Indeks dan Islamic Social Reporting Indeks. Simposium Nasional Akuntansi XIII. Purwokerto.

Ghozali, I., dan Chariri, A. (2007). Teori Akuntansi. Semarang: Badan Penerbit UNDIP.

Handoko, Y. (2014). Implementasi Social and Environmental Disclosure dalam Perspektif Teoritis. Jurnal JIBEKA, 8(1), 72-76.

Haniffa, R. (2002). Social reporting disclosure Islamic perspective. Indonesian Management \& Accounting Research, 1, 128-146.

Hartono. (2008). SPSS 16.0 Analisis Data Statistika dan Penelitian (Edisi Kedua). Yogyakarta: Pustaka Pelajar. 
Haryono, S. (2009). Analisis Laporan Keuangan Perbankan Syariah (Edisi Pertama). Indramayu: Pustaka Sayid Sabiq.

Marina, A. (2009). Akuntansi Pertanggungjawaban Sosial dalam Praktek di Perusahaan Go Publik di Indonesia. Surabaya.

Muhammad, R. (2010). Persepsi User dan Preparer Laporan Keuangan Terhadap Pelaporan Sosial Perbankan Islam di Malaysia. Jurnal Akuntansi dan Auditing Indonesia, 14(2), 189-209.

Maali, B., Casson, P., Napier, C. (2006). Social Reporting by Islamic Banks. ABACUS, 42(2), 266-286.

Setiawan, A. B. (2009). Kesehatan Finansial dan Kinerja Sosial. Jakarta.

Zain, M. M., Darus, F., Yusoff, H., Amran, A., Fauzi, H., Purwanto, Y., dan Naim, D. M. A. (2012). Corporate Ibadah: An Islamic Perspective of Corporate Social Responsibility. International Journal of Business and Technopreneruship, 2, 415-413. 